\title{
Franchise Mart-The Source of Indian Entrepreneur
}

\author{
*Upasna Joshi ${ }^{1}$, Reeta Mahei ${ }^{2}$ \\ 1Punjab School of Management Studies, Punjabi University Regional Centre, Mohali, India \\ 2Department of Commerce, Zakir Husain College, University of Delhi, India \\ *upasna_sethi@yahoo.com
}

\begin{abstract}
Most of us encounter dozens of franchised businesses each day, ranging from familiar fast-food restaurants to franchised educational systems such as Learn Right. Franchise means the special right given by the producer of a product (brand) to another firm to sell his product in a particular area. Franchising operation is a contractual relationship between a franchisor (the company offering the franchise) and the franchisee (the company undertaking to promote the sale of franchisor's products). Individual franchises are a tightly knit group of enterprises whose systematic operations are planned, directed and controlled by the operation's innovator, called the 'franchisor'. Franchising continues to be a highly regulated industry that endeavors to promote the healthy growth of the economy. As an entrepreneur is a catalyst in the process of economic development, there is a need to develop the concept of entrepreneurship. Franchise Mart is a source to develop the Indian entrepreneurs. The present paper aims to discuss the concept of franchising, reasons for franchising and different opportunities provided by franchising for development of Indian entrepreneurs. The top established and emerging franchises both national and international are also discussed in our present paper. Finally, some suggestions are given for success in franchising.
\end{abstract}

Key Words: Franchising, Franchise Mart, Franchisor, Franchisee, Entrepreneur, Business opportunities

\section{Introduction}

The contemporary business environment has opened many opportunities for the Indian entrepreneurs. Franchising is one of them. Franchising is a popular business endeavor for entrepreneurs. A perceptible trend in the growth of organized retail market has been the concept of retail franchising. According to industry estimates, retail franchising has been growing at the rate of sixty percent in the last five years and to grow two-fold in the next five years. A number of companies have been taking this route driven mainly by the need to meet the increasing consumer expectations of quality, ambience and brand experience. In the year 2000, according to the International Franchise Association (IFA) franchisors and franchisees accounted for one trillion in annual retail sales in the United States. Franchising that globally contributes almost $20 \%$ of the GDP has emerged as a successful format for retail business in India. This can be judged from the fact that franchise business today has crossed rupees 15000 crores mark and is growing at the rate of $30 \%$ per annum. Franchises now command more than $35 \%$ of all retail sales in United States (Kotler \& Armstrong, 2002). According to the website of McDonald's the first restaurant opened in San Bernardino, California as a barbeque restaurant but eight years later Dick and Mac McDonald restyled the restaurant and streamed lined the menu to nine convenient items including their famous 15\% hamburger. In 1954, a mixer salesman saw a potential in the business and opened the first franchise in Des Plaines, Illinois. In four years, the chain had grown to at least a hundred restaurants. These days, it's nearly impossible to stroll down a city block or drive on a sub urban street without seeing a McDonald's, one of the best known and most successful franchisors. Over $80 \%$ of McDonald's restaurants worldwide are owned and operated by franchisees (Andrew, 1994).

Entrepreneurship is a vital component of productivity and growth (Baumol, 1993). (Cole, 1959 )in his book has written "entrepreneurship is the purposeful activity of an individual or a group of associated individuals, undertaken to initiate, maintain and profit by production or distribution of goods and services." Entrepreneurship involves generating wealth by commercial application of innovations. Franchise system is the source for the development of entrepreneurship as it provides opportunities for launching new ventures (Das, 2010). Franchising continues to be a highly regulated industry in an effort to promote the healthy growth of the economy. The present paper aims to discuss the concept of franchising. The main objective of this paper is to discuss the different opportunities provided by franchising to develop the Indian entrepreneurs. As we know that entrepreneur is the catalyst in the process of economic development. The paper aims to give an overview about what kind of franchises 
business are there, because franchise mart is considered to be a source of development of Indian entrepreneur. The aim is also to discuss the top established and emerging franchises in India so that entrepreneurial opportunity can be judged in these also.

\section{Methodology}

For this purpose secondary source of data collection was used. Material has been collected from various related journals, books, articles etc. Different related websites have also been used for the purpose of completion of this paper.

\section{Concept of Franchising}

Franchising is the practice of using another firm's successful business model. Many believe that Albert Singer, founder of the singer sewing machine was the initiator of the franchising. He was actually the earliest person recognized by most as being associated with franchising. However, the concept of franchising really began long before. The term 'franchising' derived from ancient French, is defined as holding a particular privilege or right. As per Online Etymology Dictionary, the word franchise is of AngloFrench derivation-from Franc- means free, and is used both as a noun and a (transitive) verb. It is authorization by a company to sell its products or services. Franchising then traveled from European brewers into the United States. Before franchising, there was not much in the way of chain operations, which would eventually form the basis of franchising in the U.S. In early American history, peddlers selling items from town to town are also considered a form of franchising. Albert Singer came on the scene in 1851 with the Singer Sewing Machine Company. Singer made use of franchising to distribute his machines over a widespread geographic area. He was the first actual name recognized as an early franchisor. He was the first to prepare franchise contracts and these documents became the basis for the modern version of franchise agreements. In the late 1800's and early 1900's many other forms of franchising took place. Transportation and increasingly mobile Americans were the basis for establishment of retail and restaurant franchises.

The American Heritage Dictionary of the English Language defines "franchise" as a "privilege or right granted a person or group by a government, state or sovereign, especially suffrage...the grant of certain rights and powers to a corporation authorization granted by a manufacturer to a distributor or dealer to sell its products." Thus, franchising operation is a contractual relationship between a franchisor (the company offering the franchise) and the franchisee (the company undertaking to promote the sale of franchisor's products). Franchise systems are normally based on some unique product or service; on a method of doing business or on the trade name, goodwill or patent that the franchiser has developed. Under this system, a manufacturer grants exclusive right to sell his products or services to a selected retailer in a specified area. The retailers are required to promote and sell the product in a specified manner. The individual franchises are a tightly knit group of enterprises whose systematic operations are planned, directed, and controlled by the operator's innovator called a franchisor (Chhabra, 2009). Generally, franchises are distinguished by following characteristics:

- The franchisor owns a trade or service mark and licenses it to franchisees in return for royalty payments.

- The franchisee pays for the license and becomes a part of the franchisor's network. An initial payment has to be made and then a regular license fee. There may be an agreement on the percentage of sales or profit to be given monthly or annually by the franchisee to the franchisor.

- The franchisor provides all marketing support and proper equipment and systems for doing business in the required manner.

- The franchisee has to follow franchisor's policies regarding modes of operation of business. He is also required to maintain a particular kind of decor in the place of business.

- The franchisor may arrange training for the personnel working in the franchisee organization. This is common in case of restaurants and fast food chains.

\section{Franchise Mart: The Source of Indian Entrepreneur}

Modern retailing is growing and expanding in India at a very rapid pace with new malls. Retailing is therefore a big opportunity for the thousands of budding entrepreneurs across the country. You would have noticed that almost half of the retail outlets are related to franchised brands in case of modern 
shopping malls (Blain, 2008). Franchising is one of the important business opportunities for the development of Indian entrepreneur and especially for women because it is a great way for women to be their own bosses and run their own business without having to worry about creating and building a brand (Bains, 2008). The franchisor offers to maintain a continuing interest in the business of the franchisee in such areas as location, site selection, training of staff, financing, marketing and promotion.

The franchisees in this case need not to make huge investments in product innovation and research and development. The franchisor makes huge investments in product innovation and research and development. The benefits of these investments are passed on to the franchisee in the form of improved products. They are in a position to use the name and trade mark of the franchisor for attracting customers and increase their sales. There are greater chances of the success of franchisee because the brand of the franchiser is well known in the market (Sharma, 2006). Therefore, this reason leads to the start of more business because franchisee feels secured to some extent. In India, the concept of franchising is popular in fast food chains, beauty parlors, fitness centers, computer education centers, and departmental stores of international repute (Mamoria, Suri, \& Mamoria, 2009). Following key franchise, business opportunities are available in India. If will see the web sites of following franchises we will come to know their terms of agreements also.

Apparel Franchises: In India, this is the key franchise business opportunity. In this all kinds of clothing franchises like international brands, fashion brands, kids clothing, women apparels, discount stores, low cost franchise, and men's wear are included. There are almost 52 franchise names in this list in India like Bachhawat Retails Pvt. Ltd, Total Wardrobe Solutions for Belmonte, Bajaj Textiles, Baby Dreams, and Cottons by Century, Freedom Fashion etc. They are having own terms and conditions for franchising their brand.

Automotive Franchises: This franchising is a major part of the franchise business and also a great opportunity to start your own automobile business. This includes automobiles franchise, automotive parts, car repairs, car service centre, bike service centre, car decoration, car sales, car beauty clinic, etc. Five organizations are there in India who is offering franchising opportunity. These are:

Sarrahraj Enterprises (pvt.) Ltd: They are automotive franchisors having brand auto track India ltd. They are part of Raj group international from UAE. Sarrahraj is their latest venture in India having sole distributorship for Gujarat for auto track ltd. They started their franchise business in 2009.

Autovega Mobile Car Services: They introduced in India the concept of mobile car care. It is a professionally managed company by people with 20 years of global experience in automotive service industry. They provide mobile passenger car services. Their fully equipped and branded vans go to the car owner's site and perform pre-scheduled services.

Mahindra First Choice: Mahindra group is one of the leading automobile players in India. Other promoters include HDFC and Sah \& Sanghi, known for their retail operations in Mumbai. Their aim is to set up a nationwide chain of multi brand used car outlets that include superstores and franchisee stores. They have already appointed around seventy franchisee in fifty leading cities of the country and planned to have more than 200 stores over a period of 2-3 years. They started franchising in 2008.

Max Mobility Pvt. Ltd: A wireless applications company, having max track brand now started dealing in specialized applications using GPS/RFID devices. They started their franchisee in 2010 but not yet opened any franchisee outlet.

Man Machine works (Pvt.) Ltd: Their brand name is express car wash and they started their business as well as franchisee in 2010 having company outlets three and franchisee outlets ten.

Beauty Salon Franchises: Beauty franchise includes beauty and care, skin clinic, beauty treatment, hair care, cosmetics, Ayurvedic, beauty training, Parlour, grooming, international salon, Indian beauty salon, beauty products, hair styling franchise etc. The most famous are: Shahnaz Husain group of companies, Jawed Habib Hair Xpresso, Berkowits (offering non-surgical treatment in the areas of hair, skin and body), VLCC health care ltd and so on. VLCC today has achieved an iconic status across the world and is India's largest and most preferred slimming, beauty and health brand.

Book Store Franchises: This is a major part of the franchise business and also a great opportunity to start your own business. It includes library franchise, book franchise, online library franchise, cafe book shop, stationary franchise etc. In this category Bookmark, library system is the India's first chain of 
libraries and Apeejay Oxford bookstore Private ltd is the other to provide franchises opportunities to the Indian entrepreneurs.

Business Services Franchises: Franchise in India is a mission of the Franchise Mart in which business service franchise is the key franchise business opportunity. Today most of the organizations are seeking outside assistance from business-to-business service providers in order to manage their strategies to increase the productivity of their sales teams. There are all kinds of franchise opportunities in this sector. The franchise opportunities in this sector include consultancy franchise, job franchise, HR and placement, designing services, education and training employment services, management business, courier business etc.

\section{Cafeteria Franchises}

There are all kinds of cafeteria franchise including café, coffee shop, coffee bar, snack bar, tea room, coffee lounge, coffee and book shop, café kiosk, low investment and high profit franchise etc.

Computer and Internet Franchises: In today's business world, companies rely heavily on computers and the internet to be successful. It provides opportunity to all the entrepreneurs to choose from a variety of business concepts. It includes internet consulting businesses, computer repair franchises, web design businesses and computer service franchises.

Consultancy Franchises: It includes fields such as management consultancy, business consultancy, sales consultancy, while other similar franchise could be for you if anyone is looking for franchise business.

Education Franchises: Education franchise is also one of the major parts of the franchise business and a great opportunity to start a new venture. Pre-school franchise, play school, day care franchise, child care, learning center, training institute, grooming centre, IT institutes, recruitment services, customer services etc. are included in this category.

Entertainment Franchises: Event organizer, game zone, entertainment centre, decoration etc. are included in this business opportunity. OOVAA, 3D Animation India, Balloon man, big flix are some of the examples of such type business opportunities providers.

Footwear Franchises: This is also of the inspiring business opportunity if anyone is interested in such business. Adidas, Big shoe bazaar.com Pvt. Ltd., colors, liberty, M\&B footwear, red cooper brands are offering their franchises.

Health Care Franchises: It includes physiotherapy, ayurveda, diet, wellness, health management, medicine, skin treatment, Pharmacy Company, pharmaceuticals, gym etc. Real estate franchises, food and beverages franchises and florist's franchises are also there for the entrepreneurs to start their own business.

Top Established Franchises in India: Many companies have already marked their landmark in the industry and are instigators of vision for franchising business in India. They have created and articulated the vision passionately, and relentlessly drive it to completion. These are Mahindra First Choice Wheels, Motilal Oswal Securities Ltd., Archie's, Euro kids, Shahnaz Husain Group of Companies, Quality wall's swirl's, JK Tyres, Titan, Kid zee, Raymond, Club city, Jetking Info train Ltd., Fren's N Petals, Sagar Ratna, The Institute of Computer Accountants, Tanishq, NIIT, Career Launcher, Amul and VLCC are some of the top well established Indian franchises.

Top Emerging Franchises in India: There are many popular companies which are not the industry leaders, as yet but have made their strong presence in the market. These are: Kodack, Sharekhan, Billabong High International School, Brain Works, ICICI Securities, Cox and Kings, Dosa Plaza, Kangaroo Kids Education ltd, ZEE High etc.

Top International Franchises in India: Crossing its own geographical boundaries, there are many companies which have made their global identity (Dnes, 1993). Majority of them forayed into India and others are soon to enter (Alon, 2003). These are: Re/Max, Crest Com International, Signarama, Samsonite, South Asia Pvt. Ltd, Gloria Jeans Coffees, Chiking, Cartridge World, Alona India, Jus Booster Juice, Levi 
Strauss India Pvt. Ltd, Nokia, Pizza Hut, The Coffee Club, Marry brown, Subway, McDonald's, Adidas, The Pizza Company, etc.

Top Ten Franchises for the Year 2011: Entrepreneurs Franchise $500 ®$ is the world's first, best and most comprehensive franchise ranking based on objective, quantifiable measures of success. As per their ranking top ten franchises for the year 2011 are: Hampton Hotels, Ampm, McDonald's, 7-Eleven Inc., Supercuts, Days Inn, Vanguard Cleaning Systems, Servpro, Subway, and Denny's Inc.

\section{Conclusion}

No doubt, franchisee gets an edge over competitors in the domestic market as the brand identity of the product is already established by the franchiser but franchisee must be careful not to be cheated (Patric\& Sevgin, 1999). Proper care should be taken before selecting franchisee option. Investigations should be made about various running franchises, the number of franchisees in your area, how many more may come up in next two years, what are the service supply conditions, the profits made by the running units, the number of units that failed and why (Bibby, 2011)? Timely decisions made carefully will increase the chances of success. For growth of the franchisor and an increase in the earnings of the franchisee a strategic alliance with major outside corporations, expansion abroad and opening franchises in traditional and non- traditional site locations i.e. opening franchises in airports, convenience stores, truck stops, college campuses, sporting facilities, military bases, casinos, convention halls and even on riverboats should be considered.

Suggestions for Successful Franchising: With so many choices out there, selecting a franchise can be a very difficult task. A choice lies between different franchise ownership opportunities and franchise industries (Roberta, 1997). Following are some suggestions for success in this business.

- Before buying a franchise, you should learn more about the history of franchising and the basics of franchise world.

- If a franchise system is to be successful, a great deal rides on contract design, capable procurement, and monitoring agencies.

- How long a franchisor has been in business and how strong is his financial position and whether it allows growth is some areas need proper enquiries.

- Cross reference check from the financial institutions.

- Potential franchisees can employ franchise consultants to help to choose the correct franchise company in which to invest because franchise consulting is a specialized category of professional assistance for investors, entrepreneur.

- Leverage a well established brand that is recognized domestically and globally.

- Start with comparatively low initial establishment cost.

Finally, we can say that franchises mart is the source of Indian entrepreneurs as so many facilities are enjoyed by the franchisee to market their product. (Spinelli, Birely\& Rosenberg, 2004) explains that franchising is a pathway to wealth creation as true entrepreneurship, for every potential franchisor and franchisee ready to generate large scale wealth.

\section{References}

Andrew, E. S. (1994). McDonald's conquers the World, Fortune, Oct, 17, 103-116.

Alon, L. (2003). Economic Potential of International Franchising in Emerging Markets, U.S.A: F.T.Press.

Baumol, W. J. (1993). Entrepreneurship, Management and the Structure of Payoff, The MIT Press, Cambridge: Massachusetts.

Bibby, N. A. (2011). Why New Franchisor Fail, Retrieved from www.bibby group.com/ franchisearticles.htm- United States.

Blain, P. (2008). How to Become an Effective Franchisor, Franchising Focus, 6(1), 44-46.

Bains, D. (2008). Women in Franchising Success Story, Franchising Focus, 6(3), 17-18.

Chhabra, T. N. (2009). Entrepreneurship Development, $1^{\text {ST }}$ ed. New Delhi, Sun India Publishers: 21.1-21.3.

Cole, A. H. (1959). Business Enterprise in its social settings, Cambridge: Harvard University Press.

Dnes, W.A. (1993). Franchising Passenger Rail. Scottish Journal of Political Economy, 40, 104-115. 
Das, S. (2010). Opportunities- Retail and Franchising, Retrieved from www. dare.co.in/ opportunities/ retail- franchising.

Kotler, P., \& Armstrong, G. (2002). Principles of Marketing, $9^{\text {TH }}$ ed. New Delhi, Prentice Hall India Private Limited: 480-81.Mamoria, C.B., Suri, R.K., \& Mamoria, S. (2009). Marketing Management, $8^{\text {TH }}$ ed. Allahabad, Kitab Mahal: 441-42.

Patrick, J. K. \& Sevgin, E. (1999). Standardization and Adaptation of Business Format Franchising, Journal of Business Venturing, 14, 69-85.

Roberta, M. (1997). The decision to franchise, Nations Business, 49-53.

Sharma, S. (2006). Workbook on entrepreneurship for commerce streams, $2^{\mathrm{ND}}$ ed. Chandigarh, An ABZ Publication: 2.2.51-52. 